\title{
Stand and environmental data from Pinus halepensis Mill. and Pinus sylvestris L. plantations in Spain
}

\author{
Teresa Bueis $^{1}$ (D) María-Belén Turrión ${ }^{1,2}$ • Felipe Bravo ${ }^{1,3}$
}

Received: 22 December 2017 / Accepted: 13 February 2019 / Published online: 10 April 2019

(C) The Author(s) 2019

\begin{abstract}
- Key message This data set provides valuable environmental information about Pinus halepensis and Pinus sylvestris plantations in Spain. An array of 74 physical, chemical and biochemical soil (organic horizon and $10 \mathrm{~cm}$ topsoil), climatic, physiographic and stand variables from $32 P$. halepensis and 77 variables from $35 P$. sylvestris plantations are provided. Dataset access is at https://doi.org/10.5281/zenodo.1294607. Associated metadata is available at https://agroenvgeo.data.inra.fr/ geonetwork/srv/eng/catalog.search\#/metadata/b769554a-2e62-414a-9392-ebd307f0c76f.
\end{abstract}

Keywords Soil physical parameters - Soil chemical parameters - Soil biochemical parameters - Climatic parameters . Physiographic parameters $\cdot$ Stand parameters $\cdot$ Site index $\cdot$ Forest productivity

\section{Background}

Pinus halepensis Mill. and Pinus sylvestris L. were extensively used for reforestation of degraded areas in Castilla y León region during the last century. The knowledge about the relationships between environmental factors and stand data in forest plantations can help forest managers to achieve both protective and productive goals for these plantations and are useful for the understanding of the ecosystem functioning (Bueis

Handling Editor: Marianne Peiffer

\section{Contribution of the co-authors}

Teresa Bueis: designed the experiment, carried out the field and laboratory work, run the data analysis and wrote the paper

María-Belén Turrión: designed the experiment, supervised the laboratory analysis and corrected the manuscript

Felipe Bravo: designed the experiment, coordinated the research project and corrected the manuscript

This article is part of the topical collection on Mediterranean pines

Teresa Bueis

teresa.bueis@agro.uva.es

1 Sustainable Forest Management Research Institute, University of Valladolid \& INIA, Avda. Madrid 44, 34004 Palencia, Spain

2 Departamento de Ciencias Agroforestales, E.T.S. Ingenierías Agrarias, Universidad de Valladolid, Palencia, Spain

3 Departamento de Producción Vegetal y Recursos Forestales. E.T.S. Ingenierías Agrarias, Universidad de Valladollid, Palencia, Spain et al. 2016, 2017). Environmental parameters including climatic, topographic and soil (physical, chemical and biochemical) parameters have proved useful for estimating forest productivity (Aertsen et al. 2012; Afif-Khouri et al. 2010; Bravo-Oviedo and Montero 2005; Bravo and Montero 2001; Bueis et al. 2016, 2017; Corona et al. 1998; Hagglund and Lundmark 1977; Nieppola and Carleton 1991; Pietrzykowski et al. 2015; Romanya and Vallejo 2004; Sanchez-Rodriguez et al. 2002; Sharma et al. 2012). Forest productivity is usually estimated through stand parameters such as the dominant height (the height of the 100 thickest trees per hectare) at a reference age, because it is strongly correlated to wood production (Skovsgaard and Vanclay 2008). However, some silvicultural practices modify the dominant height of the stands leading to underestimation of forest productivity. In those cases, the methods based on environmental parameters are more appropriate (Bueis et al. 2016, 2017). Besides, soil biochemical parameters reflect the status of the soil biological activity responsible for mineralisation and humification processes and then responsible for nutrient availability in forest ecosystems (Bueis et al. 2018b; Yang et al. 2012) and are also useful indicators of health and quality in forest ecosystems (Bloem et al. 2006).

The plots of the Spanish National Forest Inventory (SNFI) constitute a very valuable source of information to monitor the evolution of the Spanish forest stands. The SNFI permanent plots are located in the intersections of a systematic $1-\mathrm{km} \times 1$ $\mathrm{km}$ grid when they coincide with forest areas. The same measurements are carried out every 10 years including the species composition of the stand, the canopy cover, the age, the diameter 
at breast height (DBH; $1.3 \mathrm{~m}$ ) and the total height of the trees, among others. Each plot consisted of four concentric circular plots with 25-, 15-, 10- and 5-m radii, where the trees with DBH higher than $42.5,22.5,12.5$ and $7.5 \mathrm{~cm}$ are measured, respectively. Additionally, in the 5-m radius subplots, the trees with DBH between 2.5 and $7.5 \mathrm{~cm}$ are counted. The information gathered in each subplot can be extended to the hectare by means of the expansion factor of each subplot calculated as the area of a hectare $\left(10,000 \mathrm{~m}^{2}\right)$ divided into the area of each subplot. Therefore, the expansion factors are 5.09, 14.15, 31.83 and 127.32, respectively, for the 25-, 15-, 10- and 5-m subplots. Detailed information about the forest stand is collected in the NFI. However, environmental information is scarcely gathered in these inventories, especially the data relative to the soil.

The Sustainable Forest Management Research Institute (iuFOR; University of Valladolid and INIA) also has a network of permanent plots in Pinus sylvestris plantations which consisted of rectangular $30 \times 20$-m plots. These plots have previously been studied to quantify the $\mathrm{C}$ sequestration in soils and forest biomass in Pinus sylvestris stands (Herrero and Bravo 2012; Herrero et al. 2016; Herrero de Aza et al. 2011).

\section{Methods}

\subsection{Study sites}

The 32 SNFI plots in Pinus halepensis plantations included in this dataset are located in the centre of the region of Castilla $y$ León (Fig. 1). The 35 iuFOR plots located in Pinus sylvestris plantations are located in the north of the region of Castilla y León (Fig. 1). Both Pinus halepensis and Pinus sylvestris are monospecific stands originated from afforestation. The geographical location (latitude and longitude), the altitude above the sea level and the gradient (slope) of each plot are shown in Table 1 (SNFI plots; Pinus halepensis), and Table 2 (iuFOR plots; Pinus sylvestris).

\subsection{Sampling and data collection}

Soil sampling and stand, climatic and physiographic data collection were done as detailed in Bueis et al. (2016) available at https://doi.org/10.3832/ifor1600-008, in Bueis et al. (2017) available at https://doi.org/10.1007/s13595-0160609-7 and in Bueis et al. (2018b) available at https://doi. org/10.1007/s13595-018-0720-z.

The height and diameter data in Pinus halepensis plantations come from the Third National Forest Inventory (19972007) and in Pinus sylvestris stands were gathered in the field (iuFOR plots) in 2010. Soil sampling and environmental data collection were carried out in Pinus sylvestris plots in autumn 2011 and in Pinus halepensis plots in autumn 2012.

The diameters of the trees included in both Pinus sylvestris and Pinus halepensis plots were determined by means of a tree calliper in two perpendicular directions and the average diameter was recorded for each tree. The local basal area of each plot was determined with the diameters of the trees in each plot. Tree height was determined with the aid of a hypsometer. The age of each stand was determined through the year of plantation provided by the Regional Government of Castilla and León, which is in charge of the management of these stands. The gradient of each plot was measured with a clinometer, and the aspect was determined with a compass.

Soil sampling was carried out in four sampling points per plot, located at a 5-m distance from the centre of the plot in $\mathrm{N}$,

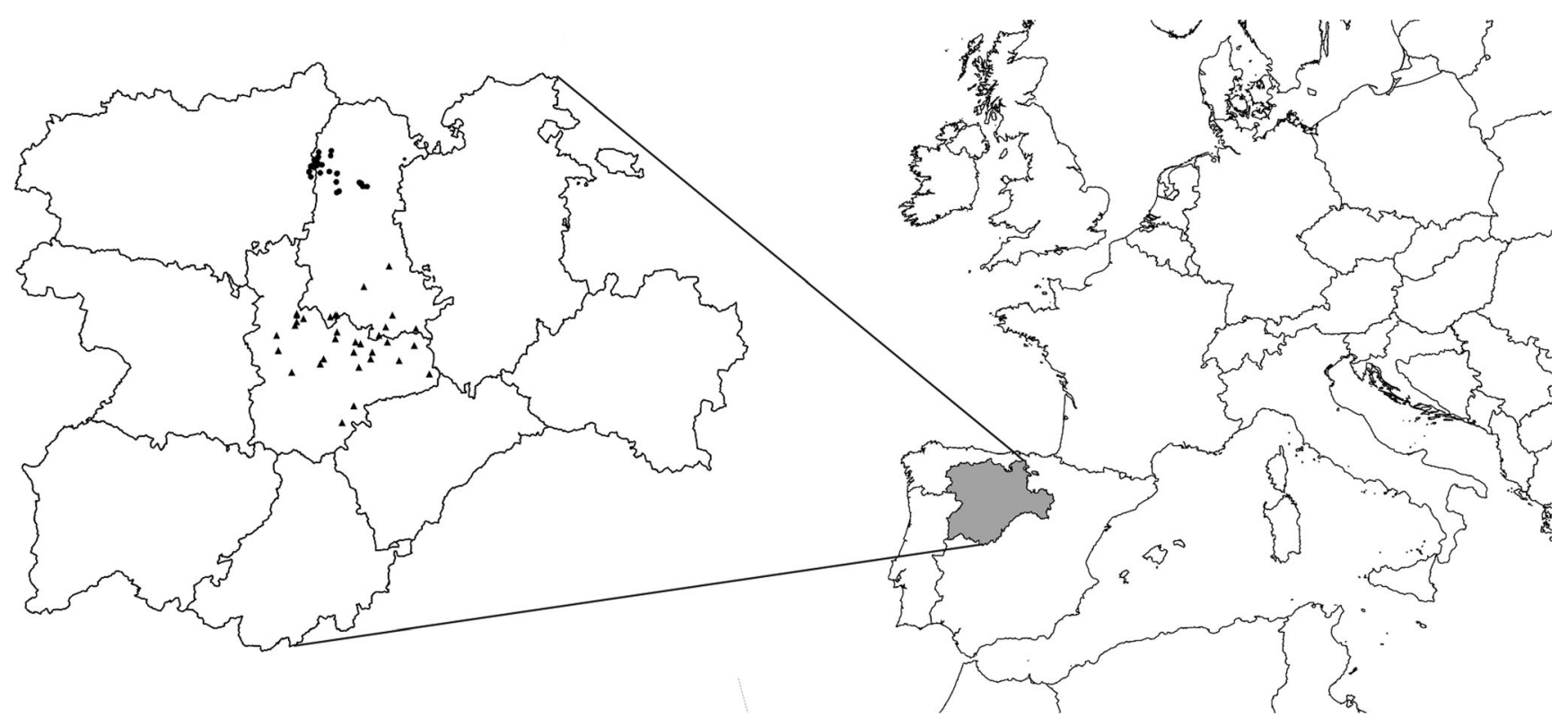

Fig. 1 Location of the plots (circles: Pinus sylvestris plots; triangles: Pinus halepensis plots) 
Table 1 Location and main characteristics of the 32 plots in Pinus halepensis plantations

\begin{tabular}{|c|c|c|c|c|}
\hline Plot name & UTM_X ${ }^{\mathrm{a}}$ & UTM_Y ${ }^{\mathrm{a}}$ & Altitude (m) & Slope (\%) \\
\hline 6 & 333,000 & $4,640,000$ & 801 & 15 \\
\hline 7 & 333,000 & $4,639,000$ & 816 & 27 \\
\hline 8 & 337,000 & $4,637,000$ & 836 & 28 \\
\hline 9 & 333,000 & $4,635,000$ & 810 & 15 \\
\hline 25 & 332,000 & $4,633,000$ & 804 & 30 \\
\hline 43 & 321,000 & $4,627,000$ & 827 & 33 \\
\hline 107 & 322,000 & $4,618,000$ & 803 & 20 \\
\hline 144 & 368,000 & $4,623,000$ & 844 & 54 \\
\hline 156 & 367,000 & $4,617,000$ & 835 & 35 \\
\hline 202 & 330,000 & $4,605,000$ & 811 & 24 \\
\hline 223 & 349,000 & $4,613,000$ & 820 & 33 \\
\hline 228 & 347,000 & $4,610,000$ & 775 & 12 \\
\hline 233 & 370,000 & $4,608,000$ & 791 & 39 \\
\hline 375 & 377,000 & $4,613,000$ & 779 & 30 \\
\hline 376 & 394,000 & $4,612,000$ & 801 & 35 \\
\hline 496 & 412,000 & $4,604,000$ & 801 & 35 \\
\hline 662 & 373,000 & $4,656,000$ & 856 & 40 \\
\hline 664 & 388,000 & $4,668,000$ & 861 & 23 \\
\hline 712 & 367,000 & $4,585,000$ & 788 & 38 \\
\hline 717 & 356,000 & $4,639,000$ & 854 & 0 \\
\hline 718 & 357,000 & $4,639,000$ & 856 & 0 \\
\hline 723 & 353,000 & $4,638,000$ & 855 & 0 \\
\hline 771 & 386,000 & $4,632,000$ & 825 & 31 \\
\hline 786 & 404,000 & $4,631,000$ & 915 & 21 \\
\hline 864 & 360,000 & $4,575,000$ & 781 & 17 \\
\hline 1237 & 390,000 & $4,639,000$ & 860 & 55 \\
\hline 1245 & 382,000 & $4,627,000$ & 829 & 11 \\
\hline 2057 & 357,000 & $4,629,000$ & 779 & 20 \\
\hline 2063 & 356,000 & $4,625,000$ & 776 & 5 \\
\hline 2070 & 371,000 & $4,622,000$ & 846 & 40 \\
\hline 2108 & 378,000 & $4,617,000$ & 769 & 25 \\
\hline 2136 & 403,000 & $4,621,000$ & 881 & 25 \\
\hline
\end{tabular}

${ }^{\mathrm{a}}$ Units: m (UTM Projection; Datum ED50)

$\mathrm{S}, \mathrm{E}$ and $\mathrm{W}$ directions. The forest floor (organic horizon) was sampled in each sampling point in a $20 \times 20$ quadrant and the $10-\mathrm{cm}$ topsoil was also sampled in each sampling point. Both the forest floor and the mineral soil samples collected in the four sampling points per plot were mixed to get a composite sample per plot.

\section{Access to data and metadata description}

The data set (Bueis et al. 2018a) is available at Zenodo digital repository: https://doi.org/10.5281/zenodo.1294607. Associated metadata is available at https://agroenvgeo.data.
Table 2 Location and main characteristics of 35 plots in Pinus sylvestris plantations

\begin{tabular}{|c|c|c|c|c|}
\hline Plot name & UTM_X ${ }^{\mathrm{a}}$ & UTM_Y ${ }^{\mathrm{a}}$ & Altitude (m) & Slope (\%) \\
\hline S1 & 356,689 & $4,711,709$ & 1005 & 0 \\
\hline S2 & 356,510 & $4,718,046$ & 1017 & 12 \\
\hline S3 & 346,008 & $4,735,864$ & 1180 & 0 \\
\hline S4 & 345,449 & $4,732,431$ & 1149 & 0 \\
\hline S5 & 356,953 & $4,723,227$ & 1075 & 0 \\
\hline S6 & 352,284 & $4,724,256$ & 1080 & 5 \\
\hline S7 & 370,257 & $4,717,777$ & 926 & 0 \\
\hline S8 & 371,299 & $4,717,225$ & 938 & 0 \\
\hline S9 & 371,111 & $4,716,897$ & 928 & 0 \\
\hline $\mathrm{S} 10$ & 372,303 & $4,715,356$ & 931 & 0 \\
\hline S11 & 356,791 & $4,722,980$ & 1069 & 0 \\
\hline S12 & 358,125 & $4,712,512$ & 981 & 9 \\
\hline S14 & 356,874 & $4,723,451$ & 1080 & 0 \\
\hline S16 & 353,086 & $4,733,717$ & 1153 & 0 \\
\hline S17 & 353,515 & $4,736,657$ & 1171 & 3 \\
\hline S18 & 347,849 & $4,728,273$ & 1095 & 3 \\
\hline S19 & 374,732 & $4,715,297$ & 958 & 5 \\
\hline $\mathrm{S} 20$ & 341,138 & $4,727,330$ & 1080 & 10 \\
\hline $\mathrm{S} 21$ & 343,309 & $4,731,280$ & 1135 & 2 \\
\hline $\mathrm{S} 22$ & 344,755 & $4,731,657$ & 1139 & 3 \\
\hline $\mathrm{S} 23$ & 344,069 & $4,729,889$ & 1118 & 5 \\
\hline $\mathrm{S} 24$ & 344,273 & $4,727,795$ & 1103 & 2 \\
\hline $\mathrm{S} 25$ & 343,114 & $4,726,676$ & 1086 & 0 \\
\hline $\mathrm{S} 26$ & 340,167 & $4,724,006$ & 1068 & 2 \\
\hline $\mathrm{S} 27$ & 340,347 & $4,724,323$ & 1062 & 0 \\
\hline S28 & 341,275 & $4,721,130$ & 995 & 8 \\
\hline S29 & 344,662 & $4,728,832$ & 1106 & 3 \\
\hline S30 & 345,725 & $4,733,054$ & 1180 & 0 \\
\hline S32 & 343,620 & $4,729,463$ & 1103 & 0 \\
\hline S35 & 341,554 & $4,727,760$ & 1041 & 0 \\
\hline S36 & 344,540 & $4,729,354$ & 1103 & 3 \\
\hline S37 & 345,010 & $4,728,213$ & 1076 & 2 \\
\hline S38 & 344,987 & $4,728,181$ & 1080 & 0 \\
\hline S40 & 345,075 & $4,728,213$ & 1078 & 3 \\
\hline S45 & 345,080 & $4,728,126$ & 1070 & 0 \\
\hline
\end{tabular}

${ }^{\mathrm{a}}$ Units: m (UTM Projection; Datum ETRS89)

inra.fr/geonetwork/srv/eng/catalog.search\#/metadata/ b769554a-2e62-414a-9392-ebd307f0c76f. The data set cover a file whose filename is Dataset.csv.

The file Dataset.csv contains information about the 74 environmental variables studied in the 32 SNFI plots (32 rows) in Pinus halepensis plantations and about the 77 environmental variables studied in the 35 iuFOR plots ( 35 rows) in Pinus halepensis plantations.

The first column (Plot) of the file Dataset.csv identifies the plot and the second column (Species) identifies the species in 
each plot (1: Pinus sylvestris; 2: Pinus halepensis). Plot characteristics include the gradient in percentage (Slope), the elevation in metres above the sea level (Altitude) and the geographical coordinates of the plots in degrees (Latitude and Longitude). Stand characteristics include the number of trees per hectare in the plot (Density), the quadratic mean diameter in centimetres $(\mathrm{Dg})$, the mean height in metres $(\mathrm{Hm})$, the dominant height in metres $(\mathrm{H} 0)$, the basal area in square metres per hectare (BA), the dominant height at the reference age ( 80 years for Pinus halepensis and 50 years for Pinus sylvestris) in metres (site index (SI)), the site quality (SQ) class and the average age in years of the trees in the plot (age).

The soil physical properties of each plot include available water (AW), coarse particles (CO), porosity (Porosity), clay content (CLAY), silt content following the USDA criteria (SILTUS), silt content following the international criteria (SILTIS), sand content following the USDA criteria (SANDUS) and sand content following the international criteria (SANDIS), all of them in percentage. The organic horizon-related parameters include the organic horizon thickness in the plot (OHT) in centimetres, the total carbon to total nitrogen ratio in the litter fraction of the organic horizon $([\mathrm{C} / \mathrm{N}] L)$, the total carbon to total nitrogen ratio in the fragmented plus humified fraction of the organic horizon ([C/N]FH), the amount of litter fraction in the organic horizon $(L)$ in tons per hectare and the amount of fragmented plus humified fraction in the organic horizon (FH) in tons per hectare.

The soil chemical parameters include $\mathrm{pH}$ value $(\mathrm{pH})$, cation exchange capacity (CEC) in centimoles of charge per kilogramme of soil, the amount of easily oxidisable $C$ in percentage (EOC), the amount of available phosphorus (AP) in milligrammes per kilogramme of soil, the total $\mathrm{N}$ (TN) in percentage, the total organic $\mathrm{C}$ to total $\mathrm{N}$ ratio (TOC/TN), the amount of exchangeable calcium, magnesium, sodium and potassium $(\mathrm{Ca}, \mathrm{Mg}, \mathrm{Na}, \mathrm{K})$ in centimoles of charge per kilogramme of soil and the water soluble phenols (WSP) in nanomoles of TAE per gramme of soil. Due to the calcareous nature of soils under Pinus halepensis plantations (SNFI plots), the following variables were also studied: the amount of carbonates (Carbonates) in percentage, the amount of reactive carbonates (React_carb) in percentage, the amount of gypsum (Gypsum) in centimoles of charge per kilogramme of soil and the amount of copper, iron, manganese and zinc $(\mathrm{Cu}, \mathrm{Fe}$, $\mathrm{Mn}, \mathrm{Zn}$ ) in milligrammes per kilogramme of soil. Similarly, due to the acidic nature of soils under Pinus sylvestris plantations (iuFOR plots), the following variables were also studied: the exchangeable acidity (EA) in centimoles of charge per kilogramme of soil, the base saturation (Sat) in percentage and the amorphous aluminium, iron and manganese (AlA, FeA, MnA), organically bound aluminium, iron and manganese (AlM, FeM, MnM) and exchangeable and inorganic aluminium (AlE, AlI) in centimoles of charge per kilogramme of soil.
The soil biochemical parameters include the amount of microbial biomass carbon, nitrogen and phosphorus (Cmic, Nmic and Pmic, respectively) in milligrammes per kilogramme of soil, the amount of mineralisable carbon (Cmin) in milligrammes per kilogramme of soil, the ratios mineralisable carbon to total organic carbon ( $\mathrm{Cmin} / \mathrm{TOC})$ and microbial biomass carbon to total organic carbon (Cmic/TOC), the microbial metabolic quotient (Cmin/Cmic; qCO2) in grammes per week and gramme of soil, the fluorescein diacetate hydrolysis reaction (FDA) in nanomoles of fluorescein diacetate per gramme of soil and minute, the dehydrogenase activity (DHA) in nanomoles of triphenyl formazan (TPF) per gramme of soil and minute, the acid and alkaline phosphatase activity (AcPhos and AlkPhos, respectively) in nanomoles of p-nitrophenyl phosphate (PNP) per gramme of soil and minute, the urease activity (Urease) in nanomoles of $\mathrm{N}$ per gramme of soil and minute, and the catalase activity (Catalase) in nanomoles of $\mathrm{O}_{2}$ per gramme of soil and minute.

The climatic parameters include mean annual temperature (MAT), mean maximum temperatures of the warmest and coldest month (MMWM and MMCM, respectively) and mean temperature of the warmest and coldest month (MTWM and MTCM, respectively) in degrees centigrade; total precipitation (TP) and winter, spring, summer and autumn precipitation (PW, PSP, PSU and PA, respectively) in millimetres; potential and real evapotranspiration (PET and RET) in millimetres; mean annual hydric deficit (Deficit) and surplus (Surplus) in millimetres; the Annual Hydric Index (AHI); and the Martonne and Lang Indexes (Martonne, Lang).

\section{Technical validation}

The validation of the datasets was carried out through a first by hand verification and complemented by numerical and graphical analyses. Laboratory equipment was regularly calibrated, and standards were used on each analysis. Soil analyses were conducted in duplicate and mean values are presented. Every record was revised in relation to the normal range of values for each variable. Related variables were examined and tested for inconsistencies basing on their correlations and corrected when necessary.

\section{Reuse potential and limits}

This original dataset includes forest stand, climate, physiography and soil physical, chemical and biochemical characteristics from Pinus halepensis and Pinus sylvestris plantations in Spain which have already been used to develop discriminant models to predict site index from 
environmental parameters useful to carry out sustainable forest management for stands. Climatic, physiographic and soil physical and chemical parameters are usually included in this kind of models. However, soil biochemical parameters are seldom included, even when soil microorganisms play a key role in soil quality and productivity (Bueis et al. 2016, 2017; Gartzia-Bengoetxea et al. 2009). They have also been used to assess the differences between the enzyme activities in the contrasting soils under Pinus sylvestris and Pinus halepensis plantations and to trace those differences back to edapho-climatic parameters to determine which environmental factors drive enzyme activities in these soils (Bueis et al. 2018b). This information is useful to state managerial proposals for improving enzyme activities and, as a result, improving nutrient availability in forest soils.

The inclusion of soil information would increase the potential use of the information in the SNFI (Alberdi et al. 2017) and iuFOR networks. Highly remarkable are the synergies between the information contained in this dataset and the information related to the forest stand available for the iuFOR and the SNFI plots. These complementary sources of information present combined interest because of their potential to unveil many aspects or dimensions of forest ecosystem functioning in Pinus plantations in Spain (Alberdi et al. 2017; Bueis et al. 2018b).

Acknowledgements The authors thank Cristóbal Ordóñez, Elisa Mellado, Temesgen Desalegn, Olga López and Carlos Alejandro Mendoza for their assistance in the field and Carmen Blanco, Juan Carlos Arranz and Adele Muscolo for their advice in laboratory analysis.

Funding This work was supported by the University of Valladolid and Banco Santander (predoctoral grant to T. Bueis), the Mediterranean Regional Office of the European Forest Institute (EFIMED; "Short Scientific Visit" grant to T. Bueis) and the Ministry of Economy and Competitiveness of the Spanish Government (AGL2011-29701-C02-02 and AGL2014-51964-C2-1-R).

\section{Compliance with ethical standards}

Conflict of interest The authors declare that they have no conflict of interest.

Open Access This article is distributed under the terms of the Creative Commons Attribution 4.0 International License (http:// creativecommons.org/licenses/by/4.0/), which permits unrestricted use, distribution, and reproduction in any medium, provided you give appropriate credit to the original author(s) and the source, provide a link to the Creative Commons license, and indicate if changes were made.

\section{References}

Aertsen W, Kint V, De Vos B, Deckers J, Van Orshoven J, Muys B (2012) Predicting forest site productivity in temperate lowland from forest floor, soil and litterfall characteristics using boosted regression trees. Plant Soil 354:157-172. https://doi.org/10. 1007/s11104-011-1052-z
Afif-Khouri E, Obregon MAC, Oliveira-Prendes JA, Gorgoso-Varela JJ, Canga-Libano E (2010) Relationship among soil parameters, tree nutrition and site index of Pinus radiata D. Don in Asturias, NW Spain. For Syst 19:77-88

Alberdi I, Cañellas I, Vallejo R (2017) The Spanish National Forest Inventory: history, development, challenges and perspectives. Pesquisa Florestal Brasileira 37:361-368. https://doi.org/10.4336/ 2017.pfb.37.91.1337

Bloem J, Hopkins DW, Benedetti A (2006) Microbiological methods for assessing soil quality. CABI Publishing, Wallingford (UK)

Bravo F, Montero G (2001) Site index estimation in Scots pine (Pinus sylvestris L.) stands in the High Ebro Basin (northern Spain) using soil attributes. Forestry 74:395-406. https://doi.org/10.1093/ forestry/74.4.395

Bravo-Oviedo A, Montero G (2005) Site index in relation to edaphic variables in stone pine (Pinus pinea L.) stands in south west Spain. Ann For Sci 62:61-72. https://doi.org/10.1051/forest:2004086

Bueis T, Bravo F, Pando V, Turrión MB (2016) Relationship between environmental parameters and Pinus sylvestris L. site index in forest plantations in northern Spain acidic plateau. iForest 9:394-401. https://doi.org/10.3832/ifor1600-008

Bueis T, Bravo F, Pando V, Turrión MB (2017) Site factors as predictors for Pinus halepensis Mill. productivity in Spanish plantations. Ann For Sci 74:6. https://doi.org/10.1007/s13595-016-0609-7

Bueis T, Bravo F, Pando V, Muscolo A, Turrión M (2018a) Soil, climatic, physiographic and stand data in Pinus sylvestris and Pinus halepensis plantations in Spain. V1. Zenodo. [Dataset]. https://doi. org/10.5281/zenodo. 1294607

Bueis T, Turrion M-B, Bravo F, Pando V, Muscolo A (2018b) Factors determining enzyme activities in soils under Pinus halepensis and Pinus sylvestris plantations in Spain: a basis for establishing sustainable forest management strategies. Ann For Sci 75:34. https://doi. org/10.1007/s13595-018-0720-z

Corona P, Scotti R, Tarchiani N (1998) Relationship between environmental factors and site index in Douglas-fir plantations in central Italy. Forest Ecol Manag 110:195-207. https://doi.org/10.1016/ s0378-1127(98)00281-3

Gartzia-Bengoetxea N, Gonzalez-Arias A, Kandeler E, de Arano IM (2009) Potential indicators of soil quality in temperate forest ecosystems: a case study in the Basque Country. Ann For Sci 66:303. https://doi.org/10.1051/forest/2009008

Hagglund B, Lundmark JE (1977) Site index estimation by means of site properties. Scots pine and Norway Spruce in Sweden. Studia Forestalia Suecica 138:38

Herrero C, Bravo F (2012) Can we get an operational indicator of forest carbon sequestration? A case study from two forest regions in Spain. Ecol Indic 17:120-126. https://doi.org/10.1016/j.ecolind.2011.04.021

Herrero de Aza C, Turrion MB, Pando V, Bravo F (2011) Carbon in heartwood, sapwood and bark along the stem profile in three Mediterranean Pinus species. Ann For Sci 68:1067-1076. https:// doi.org/10.1007/s13595-011-0122-y

Herrero C, Turrion MB, Pando V, Bravo F (2016) Carbon content of forest floor and mineral soil in Mediterranean Pinus spp. and Oak stands in acid soils in Northern Spain. For Syst 25:E65. https://doi. org/10.5424/fs/2016252-09149

Nieppola JJ, Carleton TJ (1991) Relations between understorey vegetation, site productivity, and environmental factors in Pinus sylvestris L. stands in Southern Finland. Vegetatio 93:57-72

Pietrzykowski M, Socha J, van Doorn NS (2015) Scots pine (Pinus sylvestris L.) site index in relation to physico-chemical and biological properties in reclaimed mine soils. New Forest 46:247-266. https://doi.org/10.1007/s11056-014-9459-z

Romanya J, Vallejo VR (2004) Productivity of Pinus radiata plantations in Spain in response to climate and soil. Forest Ecol Manag 195: 177-189. https://doi.org/10.1016/j.foreco.2004.02.045 
Sanchez-Rodriguez F, Rodriguez-Soalleiro R, Espanol E, Lopez CA, Merino A (2002) Influence of edaphic factors and tree nutritive status on the productivity of Pinus radiata D. Don plantations in northwestern Spain. Forest Ecol Manag 171:181-189. https://doi. org/10.1016/s0378-1127(02)00471-1

Sharma RP, Brunner A, Eid T (2012) Site index prediction from site and climate variables for Norway spruce and Scots pine in Norway. Scand J Forest Res 27:619-636. https://doi.org/10.1080/02827581.2012.685749

Skovsgaard JP, Vanclay JK (2008) Forest site productivity: a review of the evolution of dendrometric concepts for even-aged stands. Forestry 81:13-31. https://doi.org/10.1093/forestry/cpm041
Yang K, Zhu JJ, Yan QL, Zhang JX (2012) Soil enzyme activities as potential indicators of soluble organic nitrogen pools in forest ecosystems of Northeast China. Ann For Sci 69:795-803. https://doi. org/10.1007/s13595-012-0198-z

Publisher's note Springer Nature remains neutral with regard to jurisdictional claims in published maps and institutional affiliations. 